\title{
MARINE FAUNA OF MLJET NATIONAL PARK (ADRIATIC SEA, CROATIA). 6. LEPTOCARDIA*
}

\author{
Dušan ZavodniK \\ Vitomira Širole-Paje 6, Hr 52210, Rovinj, Croatia \\ (e-mail: zavodnik.dusan@gmail.com)
}

Zavodnik, D.: Marine fauna of Mljet National Park (Adriatic Sea, Croatia). 6. Leptocardia. Nat. Croat., Vol. 25, No. 2., 213-221, Zagreb, 2016.

The lancelet Branchiostoma lanceolatum Pallas, 1778, is the only leptocardian species that appears in all the European seas, everywhere in the Mediterranean, in all areas of the Adriatic Sea, and in the Black Sea. Due to the unique environmental conditions Adriatic lancelets were noted most in the northern part of Venice Bay. In other parts of the eastern Adriatic Sea lancelets have been recorded rarely, and always at locally well limited sites. Our records in the Mljet National Park seem to be the first in the island's waters. Branchiostoma was located at four stations only, at depths of from 1 to 40 metres.

Key words: Branchiostoma lanceolatum, Distribution, Adriatic Sea, Mljet National Park.

Zavodnik, D.: Morska fauna Nacionalnog parka Mljet (Jadransko more, Hrvatska). 6. Leptocardia. Nat. Croat., Vol. 25, No. 2., 213-221, Zagreb, 2016.

Kopljača Branchiostoma lanceolatum Pallas, 1778, jedini je naš predstavnik razreda Leptocardia. Nalazimo je u svim morima Europe, pa tako i kod nas. Najčešća je u sjevernom Jadranu, a drugdje njezina su naselja vrlo ograničena. Našim je nalazima utvrđeno prisustvo ove vrste u posebnim uvjetima podmorja Nacionalnog parka Mljet. Na nju su ronioci naišli na četiri mjesta, na dubinama od 1 do $40 \mathrm{~m}$.

Ključne riječi: Branchiostoma lanceolatum, rasprostranjenost, Jadransko more, Nacionalni park Mljet.

\section{INTRODUCTION}

In the world's oceans and adjacent seas, the class Leptocardia is represented by seven species (Anonymous, 1989). Out of them, in European east Atlantic waters, just one leptocardian species, the lancelet Branchiostoma lanceolatum Pallas, 1778, has been noted (VAN DER LAND, 2001). It was referred to previously by the synonym Branchiostoma lubricum Costa, 1834, and Amphioxus lanceolatus Yarrell, 1836. In the eastern Adriatic area the lancelet is named anfiosso in Italian (VAтоva, 1943), in Slovenian navadna škrgoustka (SKET, 2003), while in Croatian its popular names are bezglavka, kopljača, streličica, and suličica (VINJA, 1986).

Live lancelets are rose yellowish to whitish gray in colour. Branchiostoma is a typical cryptobenthic creature living in clean unpolluted environments. It is a typical species of well sorted coarse sands influenced by bottom currents (Pérès \& PiCARD, 1964; PiCARD, 1965; Gamulin-Brida, 1974). Animals live shallowly buried in the sediment feeding on

\footnotetext{
${ }^{*}$ In memory of my wife Nevenka Zavodnik, DSc,. who for fifty five years unselfishly encouraged and followed me on my land and sea adventures. She left us forever on March $16^{\text {th }} 2016$, at the age of eighty.
} 
microorganims and organic detritus (Anonymous, 2010). When moving, lancelets are very lively and swift. Thus when we were sieving the sediment to extract live animals and shells, the lancelets, fleeing and jumping, immediately attracted our attention. Swimming individuals move in a spiral path. An excellent review of Branchiostoma research was created by DRACH (1948). From a systematic point of view, the genus belongs to the family Branchiostomidae, order Branchiostomiformes, class Leptocardia, and subphylum Cephalochordata (PAvletić, 1965; VAN DER LAND, 2001).

Adult Adriatic Sea lancelets are about six centimetres long and of no economic value (Miličıć, 1994). Even in times of starvation, islanders have never considered them a possible supplement to their food (BAKić \& Popović, 1983; ZavodniK, 1997).

In its range, Branchiostoma lanceolatum has been recorded at depths from 1 to 60 metres. This species is noted in the eastern Atlantic Ocean from Norway to Senegal, along nearly all the Mediterranean coasts, and in western parts of the Black Sea (ZENKEvič, 1963; RIEDL, 1991; VAN DER LAND, 2001). It was recorded in all parts of the Adriatic Sea from the bays of Trieste and Venice in the north to the Otranto Strait in the south, at 1-23 m deep (Fig. 1) (Gamulin-Brida, 1967, 1974; PožAr-Domac et al., 2000; Anonymous, 2010). According to my knowledge, in the previous literature there is no information on the presence of lancelets in waters around Mljet Island, except for the notice by Vidović (1955) on the presence of Amphioxus in the Veliko Jezero at a site in Podvrti Bay, in a clayey sandy sediment, at 11-13 metres deep.

On the other hand, there is a good deal of information on the geology and geomorphology of the Mljet Island in past times, and of present National Park territory in particular (TišLJAR, 1994; BognAR \& Curić, 1995; Cukrov et al., 2011).

The best known marine natural attractions of the National Park are two depressions named Veliko and Malo jezero - Great and Small Lake. The Great Lake without doubt is one of the most researched shallow areas in the Adriatic Sea (Vidović, 1955; BulJAN \& ŠPAN, 1976; DragANOvić, 1980; BrAlić, 1990; JASPRICA et al., 1955; JuRAČIĆ et al., 1995; VučEtić, 1995; Orepić et al., 1997; Benović et al., 2000; Meić et al., 2006).

The presence in bottom sediments and geological core samples of fossil shelly microand meiofauna (Gušić et al., 1995; SoKAČ \& BAJRAKTAREvić, 1995; BABić et al., 2006) suggests that about six thousand years ago at the places of both the depressions of karst geomorphology there was a fresh water lake (JuRAčić et al., 1995) flooded in the Pliocene period. In the postglacial period, with a global sea-level rise of more than a hundred metres (De MARCHI, 1922; OppITZ, 1956; ŠEGOTA, 1968; GovorčIn et al., 2001), ingression of sea water occurred in the two depressions through a shallow channel in the area of the present-day village of Soline, resulting in the formation of two typical marine inlets with depths of 46 and 29 metres (BRALIĆ, 1990). Thus these inlets can be characterized as „karstic marine lakes” (RiedL \& OzREtić, 1969; VANičEK et al., 2000) and should not be considered „lagoons" as proposed by Wunsam et al. (1999).

The lancelet is quite common in Italian coastal waters along the northern part of the Bay of Venice (VAtova, 1949; Rossi \& Orel, 1968). In other parts of the Adriatic Sea it appears rather rarely, always in very restricted areas, usually at depths of 1 to 23 metres (VAtova, 1943, 1949; Gamulin-Brida, 1974; ZavodniK \& Kovačić, 2000). The possible reason for such distribution pattern is the nature and composition of the sediments deposited on the coastal beaches and in the shallow lagoons of Venice area by the Isonzo, Tagliamento, and other Alpine rivers (NožınA, 1971). 


\section{MATERIALS AND METHODS}

Research was conducted under the auspices of the Thais Society for Marine Research founded by the students of biology from Croatian high schools in Zagreb and Osijek, in collaboration with researchers from Allschwill, Switzerland, and Flekke, Norway (VIDMAR et al., 1996; Vidmar \& RADiša, 1997). The field work was organized during the summer school-holidays in 1995-1997, and in 2000-2002 when some ichthyologists accompanied the research team. Eleven to fourteen divers took part in each excursion.

The sandy sediment possibly suitable for lancelets was taken by skin or SCUBA divers by means of a Zahtila hand grab and/or domestic bucket (Orepić et al., 1997). Sediments from deeper areas were taken by the research vessel Vila Velebita of the IRB Rovinj Centre for Marine Research using a modified $0.1 \mathrm{~m}^{2}$ Van Veen grab.

In the Plavilo Strait (Lovrić \& KRIžovan, 1990), in a search for Amphioxus sands, grab hauls were conducted at six stations (MLJ-122-127) at distances of half a nautical mile (about $900 \mathrm{~m}$ ) between them, at depths of 24 to $51 \mathrm{~m}$..

In total 65 diving and 28 grab stations were visited (Fig. 1). Detailed information on marine areas and sampling stations have been published by KRUŽIć (2002), ZAvodNIK (2003), and ŠILETIĆ (2006).

Lancelets were extracted from sediment by sieving through $1.1 \mathrm{~mm}^{2}$ mesh and preserved in a $6 \%$ neutralized formaline solution.

\section{RESULTS}

Sandy sediments were collected by divers of the Thais Society at a number of stations within the Mljet National Park from shallow water at many stations, to a maximum of

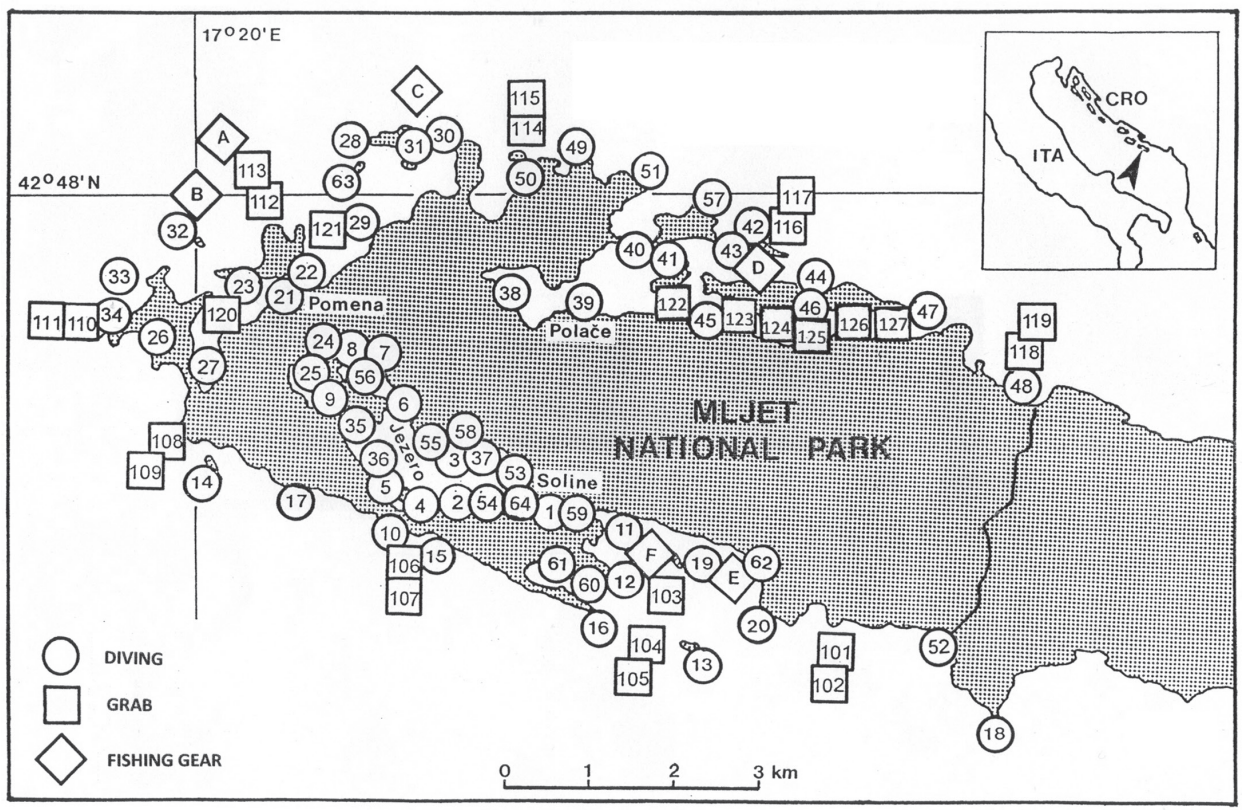

Fig. 1. Research area and stations. 
Tab. 1. Base data on stations at which lancelets occurred.

Bottom type acronyms: D - organogenic detritus, shell litter; $\mathrm{G}$ - gravel, pebbles; $\mathrm{M}$ - mud, silt; R - rock; S - sand. Community codes; Alg; algal associations; Cym - Cymodocea nodosa meadow; Det - communities of detrital sand; Pos - Posidonia oceanica bed.

\begin{tabular}{|c|c|c|c|c|c|c|c|c|}
\hline $\begin{array}{c}\text { Station } \\
\text { (MLJ-) }\end{array}$ & Locality & Depth $(\mathrm{m})$ & $\begin{array}{c}\text { Bottom } \\
\text { slope }\end{array}$ & $\begin{array}{c}\text { Bottom } \\
\text { type }\end{array}$ & $\begin{array}{c}\text { Sample } \\
\text { depth }(\mathrm{m})\end{array}$ & $\begin{array}{c}\text { Max. depth } \\
\text { surveyed }(\mathrm{m})\end{array}$ & $\begin{array}{c}\text { Number of } \\
\text { surveys }\end{array}$ & $\begin{array}{c}\text { Dominant } \\
\text { communities }\end{array}$ \\
\hline 35 & Priježba cove & 8 & gentle & RS & $1-2$ & 8 & 4 & Alg, Cym \\
\hline 36 & Podvrti cove & 42 & gentle & RSDM & 7 & 42 & 2 & Alg, Det \\
\hline 52 & Procjep cove & 65 & gentle & GRS & 40 & 42 & 3 & Alg, Pos, Det \\
\hline 56 & Njivice cape & 9 & gentle & RS & 3 & 4 & 1 & Alg, Cym \\
\hline
\end{tabular}

$46 \mathrm{~m}$ deep at station MLJ-37, and $50 \mathrm{~m}$ outwards the cliff at station MLJ-16. Lancelets were found at four locations only, all in the Veliko Jezero depression: at stations MLJ-35 (Priježba cove), 36 (Podvrti cove), 52 (Procjep cove), and 56 (Njivice cape) (Tab. 1). Branchiostoma was not found in any grab hauls by the research vessel because rocky bottoms or unfavourable coralligenous sediments were contacted. The extracted specimens were identified in our field laboratories and in the Rovinj, Centre for Marine Research according to Riedl (1963, 1991), CziHaK (1970) and an anonymous artist (2010).

In total, eight yellowish-green coloured specimens of lancelet were studied, originating from fine, well-calibrated sands collected at depths between 1 and 40 metres. Their length varied from $48-62$ millimetres. Some of the specimens were preserved and are kept in the Centre's study collection.

\section{DISCUSSION AND CONCLUSIONS}

The lancelet Branchiostoma lanceolatum is the only species of the class Acrania in the Adriatic Sea. It is a well distributed cryptobenthic species of shallow coastal areas. Although it is of no economic value (VINJA, 1986; MiLIšić, 1994), the rich etymology in the languages of the Adriatic coastal states, indicates the interest in and familiarity with the

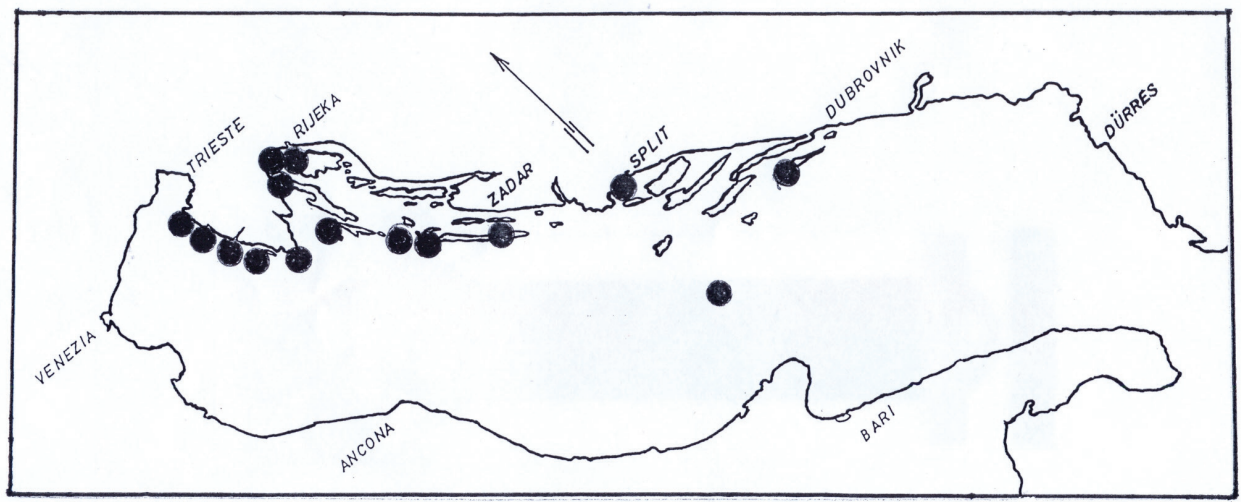

Fig. 2. Finding areas of lancelets in the Croatian sea. 
lancelet of local population and sea-farers. The morphology of Branchiostoma is discussed in detail in Croatian teaching books such as, for example, were published for Zagreb University by HabDija et al. (2004, 2011).

Branchiostoma_lanceolatum is a well distributed species in all parts of the Adriatic Sea (Anonymous, 2010), especially here and there along the Croatian littoral (Cori, 1912; VAtova, 1943; GAMulin-BridA, 1967, 1974; PožAR-Domac et al., 1998; ZAvodniK \& Kovačić, 2000) (Fig. 2). However, as early as 1885 Carus had reviewed the existing data of lancelet distribution in the Adriatic Sea. In accordance with the results of our research it appears that Mljet Island lancelet populations are not numerous and never reach the densities estimated in Amphioxus sands in the Venice Bay, at 15-23 meters depth (VAтоva, 1949).

The methodology of our research is described in details in papers by Belamarić et al. (1995), Vidmar et al. (1996), and VidMAR \& RADiša (1997). Information on the hydrology of the Mljet National Park sea was given in papers by Ercegović (1935), Buljan (1958), BuljaN \& ŠPAN (1976), Benović et al. (1995, 2000), JASPRicA et al. (1995), Juračić et al. (1995), ONOFRI \& MARguš (1995), VANičEK et al. (2000), LuČić et al. (2002) and BABić et al. (2011).

Our results on lancelets are the first to have been provided for Mljet Island waters. Although our observations may seem to be somewhat preliminary with regard to lancelet sands, it is obvious that in the area studied there is no reason for them to be specially protected (Draganović, 1980). The Branchiostoma environments seem not to be seriously endangered (BAKRAN-PETRICIOLI, 2007) except with respect to the arrival of invasive alien species, like the green alga Caulerpa_taxifolia noted recently in the area (KRUžIć, pers. comm.; ŽulJević et al., 2011). A more important danger is the constant pollution by domestic waste (Draganović, 1980), and of tourism and related services during the height of the holiday season (BELlan-SANTini et al., 1994).

\section{ACKNOWLEDGEMENTS}

I am much obliged to divers of the Thais student group for their company and help in field research, and to the director and staff of the Mljet National Park for their support in official and transport tasks. Cordial thanks also to Ms Virna Brumnić for her search of literature items, and to Ms Pamela Budicin, our granddaughter, for her help in the preparation of the manuscript by solving the secrets of modern computer programmes. Special thanks to Mrs. Ana Pranjić who edited texts written in Croatian, and to Mr. Andrea Paliaga for technical adjustment of the manuscript for print. Thanks are also due to the anonymous referees for their valuable comments and revision of the manuscript draft.

The research in Mljet National Park was partly supported by the Thais Society, the Melita Hotel in Pomena, the Centre for Marine Research of the Rudjer Bošković Institute in Rovinj, and the Natural History Museum in Rijeka.

Received June 17, 2016

\section{REFERENCES}

Anonymous (Redaction), 2009: Deuterostoma, escl. Vertebrata. In: G. Relini (Ed.), Fauna d'Italia. Fasc. 109. (Not seen). Excerpt.

Anonymous (Redaction), 2010: Acrania. In: G. Relini (Ed.), Checklist della flora e fauna dei mari italiani (Parte II). Biol. Mar. Mediterr., 17 (suppl. 1), 640.

Anonymous (Redakcija biologii), 1989: Lancetniki. Biologičeskij enciklopedičeskij slovar', Sovetskaja enciklopedija, Moskva, 310-311. 
Babić, Lj., J. Zupančić, J. Vidović, I. Razum \& M. CRnjaković, 2006: Succession of pleistocene non-marine sediments containing marine fossils, Mljet Island, eastern Adriatic (Croatia). Nat. Croat., 21(2), $269-299$.

Badovinac, Z., I. Bralić, M. Kamenarović, R. Kevo, Z. Mikulić \& O. PišKurić, 1972: Prirodne znamenitosti Hrvatske, Školska knjiga, Zagreb, 128 pp.

BAKIĆ, J. \& M. Popović, 1983: Nekonvencionalni izvori u ishrani na otocima i priobalju u toku NOR-a. In: Pomorska medicina III., Mornarički glasnik, Beograd. Pomorska biblioteka, 33, 49-55.

Bakran-Petricioli, T., 2007: Morska staništa. Priručnik za inventarizaciju i praćenje stanja. Državni zavod za zaštitu prirode, Zagreb, 148 pp.

Belamarić, J., D. Zavodnik, E. Zahtila, A. Novosel, N. Orepić, I. Ostoić, T. Radiša, M. Radošević, P. ŠKalAmera \& J. Vidmar, 1995: Preliminarni rezultati istraživanja uz vanjsku obalu Nacionalnog Parka „Mljet“. In: P. Durbešıć \& A. Benović (Eds). Mljet - Priopćenja Simpozija „Prirodne značajke i društvena valorizacija otoka Mljeta“, Pomena, Hrvatska, 4-10.9.1995. Ekološke Monografije, 6, 543-553.

Bellan-Santini, D., I. Bigot, M. Bourcier, H. Massé, J. Picard, C. Poizat \& M.-L. Roman, 1994: Les substrats meubles. In: D. Bellan-Santini, J.-C. Lacaze \& C. Poizat (Eds): Les biocénoses marines et littorales de Méditerranée, synthése, menaces et perspectives. Mus. natl Hist. nat. Paris, Patrimoines naturels, 19, 51-76.

Benović, A. (Ed.), Zbornik simpozija „Dani Branimira Gušića - Mljet 2010“, Pomena, 3-7.10.2010: Nove spoznaje iz prirodoslovlja otoka Mljeta, Nacionalni park Mljet etc. Ekološke monografije, 9, 271-278.

Benović, A., M. Carić, V. Onofri, D. Mušin \& D. Lučić, 1995. Hidrografske značajke uvale Polače - otok Mljet. In: P. Durbešić \& A. Benović (Eds), Priopćenja Simpozija „Prirodne značajke i društvena valorizacija otoka Mljeta“, Pomena, Hrvatska, 4.-10.9.1995. Ekološke Monografije, 6, 437-446.

Benović, A., D. Lučić, V. Onofri, M. Peharda, M. Carić, N. Jasprica \& S. Bobanović-Čolić, 2000: Ecological characteristics of the Mljet Island seawater lakes (South Adriatic Sea) with special reference to their resident populations of medusae. Scientia Mar., 64 (Supl. 1), 197-206.

Bognar, A. \& L. Curić, 1995: Geomorfološke značajke otoka Mljeta. In: Durbešić P. \& Benović A. (Eds), Priopćenja Simpozija „Prirodne značajke i društvena valorizacija otoka Mljeta“ , 4.-10.9.1995, Pomena. Ekološke Monografije, 6, 73-86.

BRALIĆ, I., 1990: Nacionalni parkovi Hrvatske. Školska knjiga etc., Zagreb, 160 pp.

BulJan, M., 1958: Mljetsko jezero. Pomorska enciklopedija, Leksikografski zavod FNRJ, Zagreb, 5, 300-301.

BulJan, M. \& A. Špan, 1976: Hidrografska svojstva Mljetskih jezera i susjednog mora. Acta Adriat., 6 (12), $1-224$.

Carus, J.V., 1885: Prodromus faunae Mediterraneae. E. Schweizerbart Verl. (E.Koch). Stuttgart, 524 pp.

Cori, C. J., 1912: Characteristik der Fauna der nördlichen Adria. Verh. VIII. Int. Zool.-Kongr. Graz, 1910, 689-711.

Cukrov, M., BilandžIJA, H., Cukrov, N. \& Jalžıć, B., 2011: Anhialini speleološki objekti na području otoka Mljeta. In: Durbešić P. \& Benović A. (Eds), Zbornik radova simpozija „Dani Branimira Gušića“, Pomena 3.-7.10.2010: Nove spoznaje iz prirodoslovlja otoka Mljeta, Nacionalni Park Mljet etc. Ekološke monografije, 9, 18.

CziHAK, G. 1963: Stamm: Acrania (Schädellose). In: Riedl R. (Ed), Fauna und Flora der Adria, Parey, Hamburg u. Berlin, 494-496. Zweite Auflage, 1970, 542-544.

ČAnADŽIJA, S., 1957: Bezlubanjci (Acrania). Leksikografski zavod FNRJ, Zagreb. Pomorska enciklopedija, $\mathbf{1}, 459$.

De Marchi, L., 1922: Variazioni del livello dell'Adriatico in corrispondenza colle espanzioni glaciali. Atti Acc. ven. trent. istr., 12-13, 15.

Drach, P., 1948: Embranchement des Céphalocordés. In: Traité de zoologie. Anatomie - systématique biologie. XI. Masson et al., Paris, 931-1030.

Draganović, E., 1980: Litoralne biocenoze Mljetskih jezera i problemi njihove zaštite (Mimeo). Mr. Thesis, Sveučilište u Zagrebu, 66 pp.

Durbešić P. \& Benović A. (Eds), 2011: Zbornik radova simpozija „Dani Branimira Gušića“, Pomena 3.7.10.2010. Nove spoznaje iz prirodoslovlja otoka Mljeta, Nacionalni Park Mljet etc. Ekološke monografije, 9, 400 pp.

Ercegović, A. 1934: Une contribution à la connaissance des conditions hydrographiques et biologiques du lac de l'île de Mljet (Méléda). Acta Bot. Inst. Bot. Univ. Zagrabiensis, 10, 50-60.

Gamulin-Brida, H., 1967: The benthic fauna of the Adriatic Sea. Oceanogr. Mar. Biol. Ann. Rev., 5, 537-568.

Gamulin-Brida, H., 1974: Biocoenoses benthiques de la Mer Adriatique. Acta Adriat., 15 (9), 103 pp.

Govorčin, D. P., M. Juračić, M. Horvatinčić \& V. Onofri, 2001: Holocene sedimentation in the Soline channel (Mljet lakes, Adriatic Sea). Nat. Croat., 10 (4), 247-258. 
Habdija, I., B. Primc-Habdija, I. Radanović, M. Špoljar, R. MatoničKin-Kepčija, S. Vujčić- Karlo, M. Miliša, A. Ostojić \& M. Sertić-Perić, 2011: Protista-Protozoa i Metazoa - Invertebrata. Strukture i funkcije. Alfa, Zagreb, 584 pp.

Habdija, I., B. Primc-Habdija, I. Radanović, J. Vidaković, M. Kučinić, M. Špoljar, M. MatoničKin-Miliša, 2004: Protista-Protozoa i Metazoa-Invertebrata. Funkcionalna građa i praktikum. Meridijani, Samobor, 399 pp.

Jasprica, N., D. Viličić, M. CArić \& J. NJire, 1995: Fitoplankton u Malom i Velikom jezeru (Otok Mljet, južni Jadran). In: Durbešıć Paula \& Benović Adam (Editors), Priopćenja Simpozija „Prirodne značajke i društvena valorizacija otoka Mljeta", 4.-10.9.1995, Pomena. Ekološke Monografije, 6, 453-463.

Juračić, M., I. Sondi, D. Barišıć, N. Vdović \& V. Pravdić, 1995: Sedimenti i sedimentacija u mljetskim jezerima. In: Durbešıć P. \& Benović A. (Eds), Priopćenja Simpozija „Prirodne značajke i društvena valorizacija otoka Mljeta“, Hrvatsko ekološko društvo, Državna uprava za zaštitu prirodne baštine, Zagreb \& Nacionalni park Mljet. Ekološke Monografije, 6, 107-116.

KRUŽIĆ, P., 2002. Marine fauna of the Mljet National Park (Adriatic Sea, Croatia). 1. Anthozoa. Nat. Croat., 11 (3), 265-292.

KRUŽIĆ, P., personal communication

Lovrić, P. \& Z. KRIžovan, 1990: Nacionalni park „Mljet“. Izletnička karta. Nacionalni park „Mljet“ and Zavod za kartografiju Geodetskog fakulteta Sveučilišta u Zagrebu. Mjerilo 1:14000.

Lučić, D., A. Benović, V. Onofri, V. \& M. Peharda, 2002: Zašto istražujemo Mljetska jezera? Dubrovnik, $1 / 2,277-281$.

Matjašič, J., J. Štirn, A. Avčın, L. Kubik, T. Valentinčić, F. Velkovrh \& S. Vukovič. 1975: Flora in favna Severnega Jadrana. 1. SAZU, Ljubljana, 54 pp.

McKinney, F. K., 2007: The Northern Adriatic ekosystem. Deep time in shallow sea. Columbia University Press, New York. 299 pp.

Meić, M., V. Ćosović, M. Juračić, K. Pikelj, A. PožAr-Domac, 2006: Recentna foraminiferska zajednica iz Velikog jezera (Mljet, Jadransko more). Knjiga sažetaka - Abstracts. In: Arko-Pijevac M., Kružıć B. \& Kovačić M. (Eds), II. Skup „Prirodoslovna istraživanja Riječkog podrućja“, 14.-17.6.2006., Rijeka, 84-85.

MıLıšić, N., 1994: Sva riba Jadranskog mora. Niva, Split, 463 pp.

Morović, D., 1958. Rast kamenica (Ostrea edulis L.) u Mljetskim jezerima. Acta Adriat., 6 (7), 1-28.

NožıNA, I., 1971: Rijeke sjevernog Jadrana i njihov utjecaj na fizičke osobine mora. Hidrogr. God., 1971, 41-60.

Onofri, V. \& D. Marguš, 1995: Biologija jakovske kapice (Pecten jacobaeus L.) i mogućnost njezinog uzgoja upodručju otoka Mljeta. In: Durbešıć P. \& Benović A. (Eds), Priopćenja simpozija „Prirodne značajke i društvena valorizacija otoka Mljeta“, 4.-10.9.1995, Pomena. Hrvatsko ekološko društvo, Državna uprava za zaštitu prirodne baštine, Zagreb \& Nacionalni Park Mljet. Ekološke Monografije, 6, 555-562.

OppITz, O., 1956: Jadransko more. In: Pomorska enciklopedija, Leksikografski zavod FNRJ, Zagreb, 5, 522-526.

Orepić, N. \& J. Vidmar, 1997: More, na moru otok, na otoku jezero, na jezeru otok - Mljetska jezera. Priroda, 1997: lipanj, srpanj, kolovoz, 24-27.

Orepić, N., J. Vidmar, E. Zahtila \& D. Zavodnik, 1997: A marine benthos survey in the lakes of the National Park Mljet (Adriatic Sea). Period. biol., 99 (2), 229-245.

PAvletić, J., 1965: Ribe Jadrana i srodne skupine (Leptocardia, Ciclostomata, Chondrichthyes, Osteichthyes) iz zbirke Hrvatskog narodnog zoološkog muzeja u Zagrebu. Hrvatski narodni muzej u Zagrebu, Zagreb, 26 pp.

Pérès, J. M. \& J. PiCARD, 1964: Nouveau manuel de bionomie benthique. Recl Trav. Stn Mar. d’Endoume, 31 (47) 3-137.

PiCARD, J. 1965: Recherches qualitatives sur les biocoenoses marines des substrats meubles dragables de la région marsellaise. Recl Trav. Stn Mar. d'Endoume, 36 (52) 1-160.

Požar-Domac, A., D. Zavodnik, A. Jaklin, E. Zahtila, A. Smirčić, A. Leder, G. Sinovčić, M. Radošević, G. Olujić, P. Kružić, N. Zavodnik, A. Žuljević, T. Bakran-Petricioli, M. Juračić \& B. Antolić, 2000: Project „Biodiversity preservation in the Adriatic Sea“ - Specially protected area „Palagruža". Period. biol., 102 (Suppl. 2), 49-57.

Riedl, R. (Ed), 1963: Fauna und Flora der Adria. Parey, Hamburg und Berlin, 640 pp.

RiedL, R. (Ed), 1970: Fauna und Flora der Adria (Zweite Auflage). Parey, Hamburg und Berlin, 702 pp.

Riedl, R. (Ed), 1991: Fauna e flora del Mediterraneo. Franco Muzzio, Padova, 777 pp.

Riedl, R. \& B. Ozretić, 1969: Hydrology of marginal caves. Part I. General problems and introduction. Int. Revue ges. Hydrobiol., 54 (5) 661-683. 
Rossi, S. \& Orel, G. 1968. Nota preliminare sulle „Sabbie ad anfiosso“ da Punta S'dobba a Chioggia. Boll. Soc. Adr. Sci. Trieste, 56 (2), 234-242.

Sket, B. 2003. Brezglavci - Acrania. In: Sket B., Gogala M. \& Kuštor V. (Eds): Živalstvo Slovenije. Tehniška založba Slovenije, Ljubljana, 254.

Sondi, I. \& Gušić, I., 2000: Mljet - jedinstven otok na Mediteranu. Priroda, 90 (875-877), 51-53.

Sokač, A. \& BajRakTarević, Z., 1995: Mikroorganizmi i nanoorganizmi u sedimentima Velikog i Malog jezera otoka Mljeta. In Durbešıć P. \& Benović, A. (eds), Priopćenja Simpozija 'Prirodne značajke i društvena valorizacija otoka Mljeta, 4.-10.9.1995, Pomena. Ekološke monografije 6, 127-145.

Š́gota, T., 1968: Morska razina u holocenu i mladjem dijelu Würma. Geogr. Glasnik, 30, 15-39.

TIšLJAR, J., 1994: Sedimentne stijene. Školska knjiga, Zagreb, 422 pp.

Tortonese, E., 1956: Leptocardia. Ciclostomaca. Selaci. Fauna d'Italia. 2. Calderini, Bologna (Not seen).

Van Der Land, J., 2001: Cephalochordata. In: Costello, M.J., Emblow Ch. \& White R. (Eds), European register of marine species, Mus. natn. Hist. nat. Paris, Patrimoines naturels, 50, 357.

VAničeK, V., Juračić, M., BajRaktarević, Z. \& Ćosović, V., 2000: Benthic foraminiferal assemblages in a restricted environment - an example from the Mljet lakes (Adriatic Sea, Croatia). Geol. Croat., 53 (2), 269-279.

VAtova, A., 1928: Compendio della flora e fauna del Mare Adriatico presso Rovigno. Mem. R. Com. Talass. Ital., 143, 614 pp.

VAtova, A., 1935: Ricerche preliminari sulle biocenosi del Golfo di Rovigno. Thalassia, 2 (2), 30 pp.

VAtova, A., 1943: Le zoocenosi dell'Alto Adriatico presso Rovigno e loro variazioni nello spazio e nel tempo. Thalassia, 5 (6), $61 \mathrm{pp}$.

Vatova, A., 1949: La fauna bentonica dell' Alto e Medio Adriatico. Nova Thalassia, 1 (3), 110 pp.

VIDMAR, J. \& RADišA, T., 1997: Istraživanje makrobentosa u podmorju otoka Mljeta (2). Ciljevi i metodika (ili zašto, što i kako). Priroda, 87 (835), 18-21.

Vidmar, J., T. Žerlić \& N. Orepić, 1996: Istraživanje makrobentosa u podmorju otoka Mljeta (1). Priroda, 86 (832), 22-24.

Vidović, A. 1955. Naselje dna Velikog Mljetskoj Jezera. In: Ehrlich, I., Horvatić S. \& VARičAK T. (Eds), Zbornik I. Kongresa biologa Jugoslavije, Miscellanea, Zagreb, Hrvatska, 1953. Biol. Glasnik - Period. biol., Ser. 2/B, 369-370.

VinJA, V., 1986: Jadranska fauna. Etimologija i struktura naziva. Logos, Split, 558 pp.

VučEtıć, T., 1995: O oceanografskim istraživanjima Velikog i Malog jezera na otoku Mljetu - povijesni pregled. In: P. Durbešıć \& A. Benović (Eds), Priopćenja Simpozija „Prirodne značajke i društvena valorizacija otoka Mljeta“, 4.-10.9.1995, Pomena. Ekološke Monografije, 6, 401-413.

Vuletić, A., 1953: Structure géologique du fond du Malo Jezero et du Veliko, sur l'île de Mljet. Acta Adriat., 6 (1), 1-65.

Wunsam, S., R. Schmidt \& J. Müller: 1999. Holocene lake development of two Dalmatian lagoons (Malo and Veliko Jezero, Isle of Mljet) in respect to changes in Adriatic sea level and climate. Palaeogr. Palaeoclimatol. Palaeoecol., 146, 251-281.

ZavodniK, D., 1995: Podmorje otoka Mljeta u Jadranskoj znanstvenoj literaturi. In: P. Durbešić \& A. Benović (Eds), Prirodne značajke i društvena valorizacija otoka Mljeta. Hrvatsko ekološko društvo, Državna uprava za zaštitu kulturne i prirodne baštine \& Nacionalni Park Mljet. Ekološke monografije, 6, 523553.

ZAvoDNIK, D. Field diaries 1995-2002 (unpublished).

ZavodNIK, D., 1997: Nekonvencionalni izvori hrane iz mora na tržištu istočnog Jadrana. In: FINKA B. (Ed). Tisuću godina prvoga spomena ribarstva u Hrvata, Hrvatska akademija znanosti i umjetnosti etc., Zagreb, 637-656.

ZavodnIK, D. 2003: Marine fauna of Mljet National Park (Adriatic Sea, Croatia). 2. Echinodermata. Acta Adriat., 44, 105-160.

Zavodnik, D. \& M. Kovačić, 2000: Index of marine fauna in Rijeka Bay (Adriatic Sea, Croatia). Nat. Croat., 9 (4), 297-379.

Zavodnik, D., A. Špan, N. Zavodnik, A. Šimunović \& B. Antolić, 1981: Benthos of the western coast of the island Krk (Rijeka Bay, the north Adriatic Sea). Thalassia Jugosl., 17, 285-337.

Zenkević, A. A., 1963: Biologija morej SSSR. Izd. Akad. Nauk SSSR, Moskva, 739 pp.

Zimmermann, H., 1907: Die Tierwelt am Strande der blauen Adria. Ztschr. Naturwiss., 78, 1-82.

Žuljević, A., V. Nikolić \& B. Antolić, 2011: Uklanjanje invazivne alge Caulerpa racemosa var. cylindracea u NP Mljet. Zbornik radova simpozija „Dani Branimira Gušića“, Nove spoznaje iz prirodoslovlja otoka Mljeta, Pomena, 3.-7.10.2010. Ekološke monografije, 9, 383. 


\title{
SAŽETAK
}

\section{Morska fauna Mljetskog Nacionalnog parka (Jadransko more, Hrvatska). 6. Leptocardia.}

\author{
D. Zavodnik
}

Jedina vrsta skupine kopljača (Leptocardia) koju nalazimo u Europskim morima jest Branchiostoma lanceolatum. Njezin životni areal obuhvaća more istočnog Atlantika od Norveške do Senegala i gotovo sva područja Sredozemlja sve do zapadnog dijela Crnoga mora. Također je nađena u svim područjima Jadrana, a naročito je česta u području Venecije. Živi na inače vrlo ograničenim mjestima pjeskovitog dna koje je pod utjecajem stalnih pridnenih struja. Kopljača je isključiva vrsta ovakvih staništa gdje živi plitko zakopana u površinskom sloju sedimenta.

Na području otoka Mljeta kopljača nije bila nađena sve do istraživanja studentskog društva ronioca nazvanog ,Thais“. Utvrđena je prisutnost te vrste $u$ istraživanom području Nacionalnog parka Mljet, ali uz ograničenost njezinih staništa na samo četiri mjesta u dubinama 1-40 m te vrlo nisku gustoću populacije. 